\title{
The Development of Historical Competencies in Secondary Education: A Study Based on the Analysis of Sources in Spanish and Italian History Textbooks
}

\author{
José María Álvarez-Martínez-Iglesias, Jesús Molina-Saorín, \\ Francisco Javier Trigueros-Cano and Pedro Miralles-Martínez \\ Murcia University, Murcia, Spain \\ https:// orcid.org/0000-0001-9633-3560 \\ https://orcid.org/0000-0002-9919-0910 \\ https:/ / orcid.org/0000-0002-7098-0927 \\ https://orcid.org/0000-0002-9143-2145
}

\begin{abstract}
This work presents the results of research whose main objective was to analyze the sources present in Geography and History textbooks used in Spain and Italy in secondary education, as well as how they were designed for use by the teaching staff of this subject. This research was carried out for the benefit of teachers and for the improvement of the teaching-learning process. The sample was configured on the basis of a rigorous analysis of textbooks belonging to relevant publishers in Spain and Italy, whose selection was made using a quantitative and descriptive research method based on the interpretative paradigm, with the help of an SPSS statistical program. As for the main results obtained, the data indicated that the tasks requested from students (based on the use or analysis of sources) are of a low cognitive level, which makes it difficult to learn critical and reflective historical thinking. Finally, it was concluded that for students to strengthen the development and acquisition of critical thinking, the use of textbooks must be integrated with other, more active resources and more participatory teaching strategies, putting both competency-based teaching and its assessment in quarantine.
\end{abstract}

Keywords: historical education; historical thinking; key competencies; textbooks

\section{Introduction}

Current educational research increasingly highlights the fact that customary education systems do not meet the educational needs of the younger generation, highlighting the limitations of using only the master class, amongst other methodological resources (Butchart et al., 2009; Lage et al., 2000; Schwerdt \& Wuppermann, 2011). In this sense, the excessive prominence given to textbooks 
as the main teaching resource for the teaching of History is questioned. This fact may have its origin in the fact that, throughout the years, textbooks have been identified as the most relevant source of documentary information in the classroom. This article deals with the importance of the use of sources for the teaching of the subject of Geography and History in the non-compulsory secondary education stage. This is because the use of these sources in the process of History teaching and learning constitutes a fundamental pillar for a deep knowledge of the past, as well as a means of developing historical-thinking skills amongst students, since not only must the historical discipline be learned (i.e. the acquisition of theoretical knowledge) but also the skills of the historian's work must be developed (i.e. the ability to interpret sources and provide hypotheses and conclusions about past and present reality). As a consequence of this approach, the main objective in the teaching of History is to try to ensure that students are able to carry out a critical analysis of the society around them, to interpret sources of various kinds, as well as to question the past by applying their knowledge to current problems.

In the Spanish educational system, specifically in the subject of Geography and History (non-compulsory secondary education), one of the most important aims is to form historical thought by providing students with instruments of analysis, understanding and interpretation with which they can learn History with autonomy and a critical sense. Under this paradigm, appropriately using the different historical sources that can be used in the classroom (books, memoirs, letters, autobiographies, manuscripts, speeches, photographs, paintings, images etc.) aids in carrying out the process of teaching and learning whilst contributing to the development of key competencies. In this sense, the competency of cultural awareness and expression is developed through work with sources. This is because it implies knowing, understanding, appreciating, and valuing (with a critical spirit and an open and respectful attitude) the different cultural and artistic manifestations, whilst at the same time being able to use them as a source of enrichment, as well as being considered part of the wealth and heritage of peoples.

On the other hand, linguistic competence also develops from the use of sources insofar as, for their reading and analysis, various communicative practices are employed in various modalities, formats, and supports. Similarly, the appropriate use of historical sources contributes to the development of social and civic competencies, which involve the ability and capacity to use knowledge and attitudes about society - understood from different perspectives - in its dynamic, changing, and complex conception. Precisely for this reason, it can be said that historical-temporal awareness, the contextualization of sources, the historical perspective, and the ethical dimension (skills that are characteristic of historical thought) are related to the democratic training of citizenship. This relates to the extent that they promote understanding of society and critical thought in students, thus contributing to the development of this at a social and personal level.

If we look at the strictly methodological aspects, working with sources in the classroom can be motivating for students, especially for those who are used to 
using more mechanical methods that require less personal initiative. However, taking into consideration the intellectual activity involved in working with sources (analysis of the reliability of the source, contrasting different sources, contextualization etc.), it requires students to have certain previous skills. These include, for example, a sufficient capacity for linguistic comprehension and expression, skills which, due to the new communication systems, are detrimental in today's society. For this reason, it is recommended that the use of this resource in the classroom should be frequent, whilst guided by the teacher. In this way, the student, in a progressive way, acquires the skills necessary for the use of sources in the classroom and perceives this methodological strategy as a motivating way of proceeding and useful for learning.

Amongst the authors who have stood out for their research on the use of sources, we can cite Wineburg (2001), who identified three phases experienced by students when interpreting sources. The first stage of interpretation, called provisioning, corresponds to the moment when the author of the text is sought, pursuing the reason for the event and trying to evaluate the content. In the second phase, called contextualization, an attempt is made to relate the data obtained (in the previous phase) to the social and historical context. Finally, the third level, called corroboration, is where students compare sources, looking for similarities and contradictions, with the purpose of getting to know the degree of truthfulness and realism that will help them with adequate construction and historical interpretation. As we know, many students in the subject of Geography and History find it difficult to investigate historical content. They find numerous contradictions in the sources of information, so much so that they even accept the information without having made a previous criticism for a good analysis and an adequate historical understanding. Nokes (2010) also reached this conclusion when he stated that students rarely question the reliability of sources.

Historical sources must be used appropriately to be effective resources for the teaching of History. This requires the development of basic skills in the use of historical sources that can be taught in Geography and History classes (Sáiz, 2014, 2015). In this sense, working with historical sources can therefore be a very valuable learning tool, although it is necessary to know how sources are used in the teaching of this subject. One fruitful way of approaching this is through the analysis of textbooks. The reason for this choice is that textbooks are still the main curricular material used in the classroom, as Valls and Parra (2016) pointed out is the case in Spain, and in a similar way to what has been done in other countries.

The CLIO 92 association (interested, for decades, in the effectiveness of historical didactics) highlighted three core factors for the transmission of learning or the teaching of History to students: school programs, didactic mediation, and learning processes (Trigueros et al., 2017). The three factors influence each other in such a way that the effectiveness of the structure facilitates didactic mediation (and motivates and facilitates learning), effective didactic mediation improves the quality of the structure (and deals with the learning process), and the learning process - well attended to - gives meaning to the structure of historical knowledge (and to the acts of mediation). Under this approach, it can be stated that History 
is taught and learned as a discipline in which the skills of memorization ordered from logical patterns, as well as the skills of oral expression, are substantially at stake.

After analyzing the cognitive needs printed in the educational programs of countries such as Spain or Italy, it can be seen that they are of a very simple level. This inevitably triggers a memoristic learning of the contents, a fact that is often reflected in the assessment instruments used by the teaching staff (Gómez et al., 2018).

In the field of Social Science teaching, researchers have emphasized the need to focus the teaching of History from a very important perspective: the need to develop the skills and competencies necessary for young people to live the present by interpreting it consciously. The urgency of doing so is, if anything, exacerbated by the situation of high youth unemployment which currently punishes Europe, with $42 \%$ unemployment amongst young people under 25 . This displays, in some cases, a worrying mismatch between the expectations of the system and the skills displayed by its graduates.

It should not be overlooked that, in recent years, although there have been positive developments in the definition of specific learning outcomes, it is no less true that these have also been the result of a better adjustment between the methodologies and assessment instruments that have been designed to support the learning process. Therefore, in the field of History teaching, an approach is sought which emphasizes the more disciplinary and methodological dimension of this subject. Such approach was born in England within the framework of alternative curricular projects to traditional History teaching, combining innovation and research. It spread in the 1980s and 1990s in the field of research and was restricted to countries such as the United States and Canada. It also spread in Spain, Portugal, Italy, and Brazil and has been identified with the term "historical thinking" (constituting a paradigm of reference in the teaching of History) (Gómez et al., 2020).

In pursuit of this improvement and innovation in teaching, the path opened up by historical thought offers both opportunities for cognitive development and resources for responsible and critical citizenship education (Borghi et al., 2015; Pagès, 2009; Prats \& Santacana, 2011). In the latest works on the subject, the international line of research followed in Italy for the teaching of History through this paradigm of historical thought has been formulated mainly by several authors (Borghi \& Dondarini, 2013; Borghi \& Galletti, 2020; Brusa \& Cecalupo, 2000), in a similar way to what has happened in Canada and the United States (Clark, 2011; Lévesque, 2008; Seixas \& Peck, 2004; VanSledright, 2014; Wineburg, 2001). Notwithstanding, the origin of this paradigm is an inheritance of those innovation and research paths that emerged in the United Kingdom between the 1970s and 1980s (Lee, 2005, 2011). Recently (in Spain), the proposals of historical thought have also been synthesized in various studies (Carretero \& López, 2009; Gómez et al., 2014), which have been duly reformulated and directed based on 
proposing pedagogical practices that stimulate such historical thought (Domínguez, 2015).

\section{Method}

\subsection{Objectives}

The main objective of this work was to analyze both the presence of sources in Geography and History textbooks used in Spain and Italy, and to evaluate the use of these sources by teachers during the secondary education stage. This objective has been divided into two specific objectives: SO1) to analyze the sources present in the teaching units of Geography and History textbooks in Spain and Italy (which deal with the subject of the Cold War), and SO2) to evaluate how the sources are used in these teaching units for the acquisition of the learning proposed in them. In order to achieve the proposed objectives, a quantitative and descriptive research method was chosen, framed by the interpretative paradigm.

\subsection{Sample}

For the choice of the sample, it was decided to use textbooks corresponding to the second stage of secondary education (non-compulsory), since the curricular content of that stage amply demonstrates the use of the sources in such manuals. Specifically, the educational level chosen for the selection of the textbooks was first year of baccalaureate for the Spanish case (corresponding to pupils of 16-17 years of age), and fifth year of secondary school (Human Sciences School) for the Italian case (corresponding to pupils of $17-18$ years of age).

For the selection of the publishers of textbooks, a non-probabilistic procedure was followed, from which ten were selected from amongst those that met two basic criteria for inclusion: 1) manuals whose edition corresponded to the last current edition date (between 2015 and 2018), and 2) manuals that were amongst the best-sellers (in recent years) in Spain and Italy. For the Spanish case, the publishers chosen were Anaya, Oxford, Santillana, SM, and Vicens Vives; for the Italian case, the publishers selected were Pearson, Zanichellde, Palumbo Editore, La Nuova Italia, and La Scuola. (See Appendix for bibliographic information of the selected textbooks.)

To develop and achieve the specific objectives indicated above (SO1 and SO2), it was necessary to select content that, on the one hand, has the preceptive normative curricular reference to allow it to be approached as a subject of study and, secondly, that it is content with sufficient relevance (and with the capacity to motivate) to awaken in students the emotion to know. Precisely for this reason, and in accordance with the current curriculum (in Spain) for the baccalaureate stage (included in Real Decreto [Royal Decree] 1105 [2014] - which establishes the basic curriculum for compulsory secondary education and the baccalaureate), and also what is expressed (in Italy) through the national program of Geography and History (included in Decreto Presidente della Repubblica [Presidential Decree of the Republic] [2009], n. 81 and Legge [Law] 6 August 2008, n. 133), the theme selected was the Cold War. This theme was selected precisely because the Cold War was a broad historical period (1947-1991) in which the main powers of the twentieth century intervened, and which - with great ease - can be studied with 
simplicity from sources of various kinds (texts, photographs, posters, caricatures etc.). In the same way, and in the case of Italy, this topic is also duly included as curricular content for the subject of Geography and History.

\subsection{Instrument}

For the collection of information from textbooks, an analysis tool was designed and validated, defined from the following eight categories: reference, location, nature, contextualization, provisioning, function, cognitive demand, and cognitive level. The "reference" category allows for the systematization of the bibliographical data of the work. In the "location" category, the position of the source is included in relation to the structure of the topic (specifically with the variables introduction, body, and end of the topic). Likewise, the "nature" category allows the information collected to be grouped according to the order of the source (primary or secondary) and its code (visual or textual). The fourth category, "contextualization," makes it possible to indicate the relationship of the source to the content to which it refers (unrelated, relationship to the context, and direct relationship to the content).

The "provisioning" category facilitates the collection of information about the author, place, year, and genesis of the source (purpose or information related to the source context). In the final stretch, the category "function" allows for the indication of whether the source is used as an illustration of the content or whether it has a didactic use. Finally, the categories "cognitive demand" and "cognitive level" are closely related to the activities. As such, the first category classifies the activities according to the cognitive demand they require from the students (for which attention has been paid to the verbs included in the statements). The second category (cognitive level) makes it possible to classify the activities on an ordinal scale of 1 to 3 (according to the cognitive difficulty they possess).

As for the instrument, although its design is based on the review and adaptation of similar ones already published, it was also subjected to a validation process. This process was carried out by six external experts (two university professors from the field of Didactics of Social Sciences, two professors of History - in high school, and two teachers of secondary education and baccalaureate from the department of Humanities).

Once the design was completed, the validation of this instrument was carried out through the development of another one specifically designed for the validation team. During this process, the experts enquired into the suitability of each of the categories involved in the objective of the research, as well as into the structure, substance, and form of this instrument. For the evaluation, a Likert-type scale was used with values ranging from 1 to 4 ( 1 - not suitable, 2 - not very suitable, 3 -suitable, and 4 - very suitable). The reliability of the instrument was determined through applying Cronbach's alpha coefficient using an SPSS statistical program (version 19). As a result of this application, the coefficient reached the value of 0.83 , surprisingly exceeding the optimum cut-off point for this type of study (0.70). For the analysis of the data, Microsoft Excel was used, by 
virtue of which it was possible to calculate both the absolute frequency and percentage of the variables under study, also allowing for the making of graphic representations that were incorporated in this work.

\section{Data Analysis and Discussion}

Once the analysis of the data was completed and in response to the first specific objective that was set out in the research (SO1: to analyze the sources present in the teaching units of the Spanish and Italian Geography and History textbooks which deal with the subject of the Cold War), it was concluded that, together, the ten publishers offered a total of 808 sources in the teaching units referring to the Cold War in their manuals for the subject of Geography and History (Table 1). In particular, 450 sources appeared in the Spanish textbooks, of which $69.3 \%$ were primary sources and $30.7 \%$ were secondary sources. In the case of the Italian History textbooks, 358 sources appeared, of which $79.1 \%$ were primary sources and $20.9 \%$ were secondary sources. These statistics are displayed in Table 1.

Table 1. Sources present in Cold War units in the Spanish and Italian textbooks

\begin{tabular}{|c|c|c|c|}
\hline Publisher & Total sources & Primary sources & Secondary sources \\
\hline \multicolumn{4}{|l|}{ Spanish } \\
\hline Anaya & 57 & 30 & 27 \\
\hline Oxford & 89 & 69 & 20 \\
\hline Santillana & 93 & 56 & 37 \\
\hline SM & 90 & 72 & 18 \\
\hline Vicens Vives & 121 & 85 & 36 \\
\hline Spanish total & 450 & $312(69.3 \%)$ & $138(30.7 \%)$ \\
\hline \multicolumn{4}{|l|}{ Italian } \\
\hline La Nuova Italia & 110 & 82 & 28 \\
\hline La Scuola & 100 & 85 & 15 \\
\hline Palumbo & 34 & 25 & 9 \\
\hline Pearson & 46 & 36 & 10 \\
\hline Zanichelli & 68 & 55 & 13 \\
\hline Italian total & 358 & $283(79.1 \%)$ & $75(20.9 \%)$ \\
\hline Total & 808 & $595(73.6 \%)$ & $213(26.4 \%)$ \\
\hline
\end{tabular}

As for the typology of the primary and secondary sources included in the educational units related to the Cold War, we found that, for the Spanish textbooks, $72.4 \%$ were visual and $27.6 \%$ were textual. Therefore, we can affirm that photographs are most frequently used, followed by posters of the time and caricatures, whereas in the case of the textual primary sources, what were most abundant are fragments of political speeches of relevant characters, as well as treatises of the time. On the other hand, in the Italian History textbooks, $78.7 \%$ of the sources were visual and $21.3 \%$ were textual. This shows the same tendency as in the Spanish case, although the most frequent visual sources here were not photographs but maps, with a frequency of $51 \%$ (of the total visual sources). Finally, and within the primary textual sources most frequent in the Italian textbooks - as in their Spanish counterparts - political speeches and treatises were the most frequent $(61.4 \%)$. 
With regard to the second specific objective (SO2: to evaluate how the sources are used in these teaching units for the acquisition of the learning proposed in them), it is important to highlight that in the teaching units analyzed, we found that $60.2 \%$ of the activities (142 of a total of 236) had some kind of source present in the Spanish textbooks for their use by students. However, in the Italian case, this percentage was $32.18 \%$ (56 out of a total of 174 activities). This means that the distribution of activities by publishers is unequal. In this respect, Anaya (in the Spanish case) and Palumbo (in the Italian case) are the publishers which destined the least number of activities regarding working with sources, whilst Vicens Vives and La Scuola are the publishers (Spanish and Italian, respectively) which included the most activities with the requirement of the use of sources (Table 2).

Table 2. Activities and sources used on the subject of the Cold War

\begin{tabular}{lccc}
\hline Publisher & $\begin{array}{c}\text { No. of } \\
\text { activities }\end{array}$ & $\begin{array}{c}\text { Activities with } \\
\text { sources }\end{array}$ & $\begin{array}{c}\text { Sources used in } \\
\text { activities }\end{array}$ \\
\hline Spanish & & & \\
\hline Anaya & 19 & $9(42,9 \%)$ & 16 \\
Oxford & 39 & $22(56,4 \%)$ & 22 \\
Santillana & 67 & $42(62,7 \%)$ & 53 \\
SM & 54 & $25(46,3 \%)$ & 31 \\
Vicens Vives & 57 & $44(77,2 \%)$ & 54 \\
\hline Spanish total & $\mathbf{2 3 6}$ & $\mathbf{1 4 2}(\mathbf{6 0 . 2} \%)$ & $\mathbf{1 7 6}$ \\
\hline Italian & & & 7 \\
\hline Palumbo & 23 & $7(30,4 \%)$ & 10 \\
La Nuova & 35 & $8(22,9 \%)$ & 8 \\
Italia & & & 25 \\
Pearson & 29 & $4(13,8 \%)$ & 30 \\
Zanichelli & 40 & $15(37,5 \%)$ & $\mathbf{8 0}$ \\
La Scuola & 46 & $\mathbf{2 2 ( 4 7 , 8 \% )}$ & $\mathbf{2 5 6}$ \\
\hline Italian total & $\mathbf{1 7 3}$ & $\mathbf{5 6 ( 3 2 . 1 8 \% )}$ & \\
\hline Total & $\mathbf{3 7 9}$ & $\mathbf{1 9 8}$ & \\
\hline
\end{tabular}

Of the sources included in the activities (cited above), $47.3 \%$ were for educational purposes, whilst $52.6 \%$ were used for illustrative purposes only, namely to accompany the story of the events, especially in the case of the primary visual sources (photographs, posters, drawings, paintings etc.). Therefore, it can be said that there is an almost equal distribution between the use of sources for illustrative purposes and their didactic use in the activities included in the Cold War themes of the Spanish textbooks analyzed. In the case of the Italian History textbooks, the proportion of sources with a didactic use was somewhat higher $(51.8 \%)$, whilst the percentage of sources used with an illustrative function was $48.2 \%$.

On the other hand, upon analyzing the statements of the activities, it can be seen that - for the selected publishers of both countries - the activities more often required students to answer direct questions such as "what", "who", or "when", or to explain historical facts which are explained in the unit (Figure 1), requiring the students to learn operations based on the memorization of the contents. 


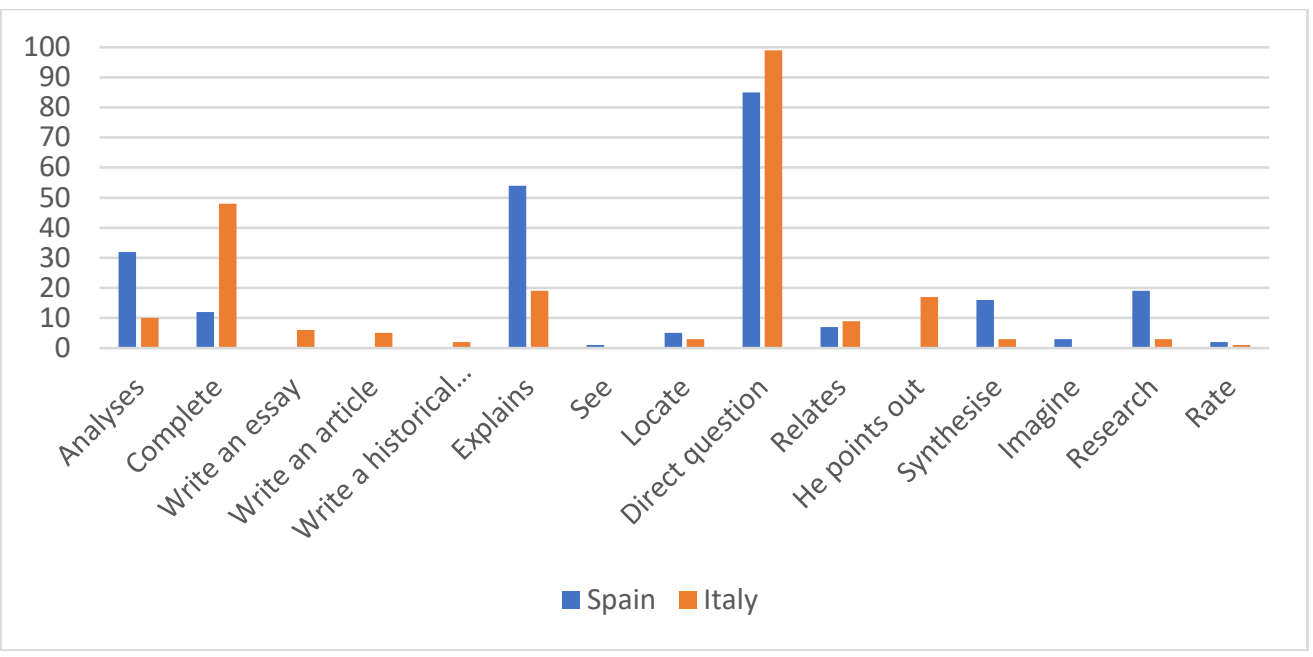

Figure 1. Most commonly used verbs in textbook activity statements

Furthermore, a comparison was made with similar studies carried out in other countries. We found that the number of sources included in the teaching units in the Spanish and Italian History textbooks was very similar to that obtained by Van Nieuwenhuyse (2016) in his comparative study on the Cold War in French and English textbooks, where the presence of primary sources was $72 \%$ compared to $28 \%$ for secondary sources. This author, however, pointed out notable differences in the typology of sources between England and France. In French books, the presence of primary sources in Geography and History textbooks reached 83\%, whilst in English books, it only reached 17\%. In the specific case of the Spanish and Italian textbooks analyzed, the figures were closer to the French case than to the English one. The main reason for this is the commitment of the English teaching system in favor of the promotion of critical historical thought based on the historiographic analysis of the facts.

On the other hand, it is important to point out that, in Spain and Italy, the historiographical debate hardly appeared in Geography and History textbooks. In addition, despite the fact that the curricula of both countries include student analysis of sources, these are usually (and as the data show) primary sources. In fact, most of the secondary sources appearing in the textbooks analyzed are not texts but maps, which highlights the fact that there are very few instances where textbooks (Spanish or Italian) contain a historiographical text to present to students.

In the case of Spain, the abundance of maps was also due to the existence of an evaluation criterion included in the curriculum and referring to identifying and explaining the conflicts of the Cold War from historical maps. In the case of primary textual sources, what were most abundant (in both countries) are fragments of political discourses of relevant figures and treatises of the time. These results are slightly higher than the data offered by Van Nieuwenhuyse (2016) for France and England, where the presence of visual sources reached 60\%.

As for the role of sources in History textbooks in Spain and Italy, there was an almost equal distribution between the use of illustrative sources and their didactic 
use. These results are very similar to those obtained from research on English textbooks. In particular, Van Nieuwenhuyse (2016) estimated that, in English textbooks, $53 \%$ of primary visual sources have a didactic use, whilst $47 \%$ serve to illustrate content. Furthermore, the number of activities in a textbook is not significant in terms of whether or not they are used for teaching purposes. This can be clearly seen, for example, in the comparison between the presence of primary sources in French and English History textbooks, the former including more sources but assigning less didactic use to them in relation to the latter. In the Spanish case, the didactic use of sources responds, fundamentally, to the compliance with the curricular provisions referred to the subject of Geography and History. In particular, Real Decreto [Royal Decree] 1105 (2014) includes several learning standards related to the use of sources for learning about the Cold War. On the one hand, these refer to the location and explanation (from historical maps) of the countries belonging to the two opposing blocks and the main conflicts developed during the Cold War. On the other hand, they refer to the request of students for the identification and explanation of the two opposing blocks as a result of the extraction of information from different sources (texts, images, maps, and graphics).

The above fact makes it possible, in principle, to attain to the learning standards included in the current educational curriculum. However, the level of cognitive demand associated with these standards is very low insofar as work with sources is limited to students identifying the blocks they face and explaining their characteristics or specific facts of this period. In the curriculum, reference is only made to the reliability of the source when students are asked to search for sources in libraries or on the internet, a fact which may be related to the inclusion of digital competence in the secondary and baccalaureate curriculum. It is striking that textbooks hardly ask students to question the reliability of sources, at least where activities with sources are presented. This is not even the case when these sources are of a historiographic nature (or are posters and cartoons), where the understanding of the approach or the intention of the author is of vital importance.

In Spain and Italy, work with the sources present in the textbooks is practically non-existent, since analysis, with excessive frequency, showed that the key concepts did not appear to be related to historical thought. Students are thus kept from completing the acquisition of critical and reflective thinking by virtue of which they are able to analyze and discern the past history and the present that surrounds them. In the same way, in the published textbooks of both countries, primary sources were more frequent than secondary ones, undoubtedly due to the decorative and illustrative character of the former. However, this fact can sometimes be counterproductive for the teaching and learning process of students, since in this way they are not presented with clear contextual or bibliographical references. This is due to the inflexible nature of the curriculum and the somewhat erroneous conception that teachers may have of the interlocking nature and architecture of its different elements. Here, current educational legislation gives greater importance to theoretical and disciplinary knowledge, leaving the much-needed competency-based education proposed for 
this stage in the background. Teacher training is also linked to this, since both in universities and in the continuous training offered by the Administration, the necessary training is not being offered to carry out these procedural and attitudinal methodologies that favor the use of resources (such as sources). This leaves the Geography and History class relegated to a mere transmission of oneway information whereby, in the long run (with technological advances and the availability of information), the student would feel that he or she could do without the teacher.

As has already been demonstrated, there is no point in applying methodologies that favor procedural learning if resources, activities, or assessment are not subsequently adapted. As an example, the fact of working with a methodology that favors procedural and attitudinal operations in the students, and later evaluating the students with a conceptual exam, only causes them confusion and anxiety in the face of this contradictory way of presenting and working with knowledge. For this reason, on many occasions, the use of sources and their integration into the teaching program ends up being displaced to the sphere of exceptionality, and not as an ordinary means of teaching for the acquisition of content.

Another relevant aspect of the analysis carried out is that the verbs contained in the statements that define the activities with sources are, for the most part, announcers of actions that require neither a process of reflection nor a critical analysis. They are proposals that propose the carrying out of a whole series of intellectual actions based on the request for reproduction of the content already explained throughout the written subject. Unfortunately, this fact is repeated in both the Spanish and Italian Geography and History textbooks, enclosing, in turn, an implicit relationship between the curriculum and the programming of objectives of the subject of History for both countries. For this reason, to carry out the work with sources correctly, teachers must adapt the materials they use (or even the questions contained in the subject manuals), so that they can correct the lack of coherence between the proposal contained in the curriculum and teaching practice.

Furthermore, in these statements, we find that the learning objectives are mostly of a conceptual nature. Very rarely do they include skills associated with historical competencies that activate this greater cognitive capacity when it comes to solving the activities. This notes a relationship between the low cognitive level of the activities analyzed and the objectives and assessment criteria included in the curriculum of the subject of History. Consequently, and in general, the most demanding task for students is the search for information and its reproduction without any analysis of the information. In other words, there is a misuse of sources since they are used exclusively for the achievement of conceptual and memoristic learning. In fact, and despite the significant number $(53.4 \%)$ of sources associated with the activities, on many occasions, students are not asked to analyze these sources. Rather, direct questions are asked, the answers to which (demanded of the students) already appear explicitly in the source itself and, as a 
consequence, could be acquired by making a descriptive reading of it with a low cognitive commitment for the student.

\section{Conclusion}

The results obtained showed that most of the activities in the analyzed textbooks were not designed to analyze and develop second-order concepts related to historical thought. Rather, their purpose is to strengthen the memorization of dates, facts, or relevant historical figures. In other words, the aim is for the student to be able to reproduce an academic discourse (presumably illustrated) in which the institutional story takes precedence over other more socio-critical approaches. This line of memorization of a standardized historical narrative is maintained, to a good extent, by the demands of the curriculum, and also by the nature of the university entrance exam. These propose to students the evaluation of learning based fundamentally on the sum of knowledge, leaving aside the acquisition of critical thinking skills and, more importantly, confirmation of the absolute oblivion of that great forgotten to this table: the transfer of knowledge. Certainly, in the scenario in which we find ourselves, and looking back over several decades in which this scenario of learning by competencies did not exist, if we believe that today (broadly speaking), it is evaluated in the same way - or furiously similar as it was in 1990 (in the midst of the implementation of the General Organic Law of the Education System [GOLES]), surely and following the maxim of 'tell me how you evaluate and I'll tell you how you teach' (Molina et al., 2017, p. 170), we will be able to say two things. First, not only are we not doing well (in terms of non-compliance with the regulations in force today), and second, conceptually speaking, if it is not evaluated by competencies, it will certainly not have been taught by competencies.

Evidently, this makes us suspect (as a line for future research) that, probably, what has been intended has been a simple semantic change. By virtue of this change, and after applying (Fierabrás') balsam which grants a new language (apparently modern and well sounding), there would have been nothing left but mirages of a purpose that no one has finally proved (if it is really taught and assessed by competences). This will surely be because the capricious inventors of its engineering had as much faith in its destiny as intelligence showed when designing it.

\section{References}

Borghi, B., \& Dondarini, R. (2013). Sobre los hombros del gigante: Legados y recursos de la historia [On the shoulders of the giant: Legacies and resources of history]. In J. A. Bresciano (Ed.), La memoria histórica y sus configuraciones temáticas: Una aproximación interdisciplinaria [Historical memory and its thematic configurations: An interdisciplinary approach.] Ediciones Cruz del Sur.

Borghi, B., Dondarini, R., \& Manari, R. M. (2015). La democrazia si impara: Per una pedagogia della cittadinanza [Democracy is learned: For a pedagogy of citizenship]. In B. Borghi, F. F. García-Pérez, \& O. Moreno-Fernández (Eds.), Novi cives: cittadini dall'infanzia in poi [New citizens: Citizens from childhood onwards] (pp. 20-27). Pàtron Editore.

Borghi, B., \& Galleti, F. (2020). Research, projects and experiences in didactics of History and Heritage from the Dipast Center of the University of Bologna, Italy. In 
E. J. Delgado-Algarra \& J. M. Cuenca-López, Handbook of Research on Citizenship and Heritage Education (pp. 1-17). IGI Global.

Butchart, S., Handfield, T., \& Restall, G. (2009). Using peer instruction to teach philosophy, logic and critical thinking. Teaching Philosophy, 32(1), 1-40. https://doi.org/10.5840/teachphil20093212

Brusa, A., \& Cecalupo, M. (2000). La terra abitata dagli uomini [The land inhabited by men]. Progedit.

Carretero, M., \& López, C. (2009). Estudios cognitivos sobre el conocimiento histórico: Aportaciones para la enseñanza y la alfabetización histórica [Cognitive studies on historical knowledge: Contributions for teaching and historical literacy]. Enseñanza de las Ciencias Sociales [Teaching for Social Sciences], 8, 75-89. https://www.raco.cat/index.php/EnsenanzaCS/article/view/184396

Clark, P. (Ed.). (2011). New possibilities for the past: Shaping History education in Canada. UBC Press.

Decreto Presidente della Repubblica [Presidential Decree of the Republic]. (2009). (2009, March 20, no. 81; in GU, 2009, July 2, no. 151) Norme per la riorganizzazione della rete scolastica e il razionale ed efficace utilizzo delle risorse umane della scuola, ai sensi dell'articolo 64, comma 4, del decreto-legge 25 giugno 2008, n. 112, convertito, con modificazioni, dalla legge 6 Agosto 2008, n. 133 [Rules for the reorganization of the school network and the rational use of the human resources of the school, pursuant to article 64, paragraph 4, of the decree-law of 25 June 2008, no. 112, converted, with modifications, by the law 6 August 2008, no. 133].

Domínguez, J. (2015). Pensamiento histórico y evaluación de competencias. [Historical thinking and competence assessment] Graó.

Gómez, C. J., Monteagudo, J., \& Miralles, P. (2018). Conocimiento histórico y evaluación de competencias en los exámenes de educación secundaria. Un análisis comparativo España-Inglaterra [Historical knowledge and assessment of competencies in secondary exams: A comparative analysis Spain-England]. Educatio Siglo XXI [Century Education XXI], 36(1), 85-106. https://doi.org/10.6018/j/324181

Gómez, C., Ortuño, J., \& Molina, S. (2014). History education under the new educational reform in Spain: New wine in old bottles. History Education Research Journal, 12(2), 122-132. https:// doi.org/10.18546/herj.12.2.10

Gómez, C. J., Solé, G., Miralles, P., \& Sánchez, R. (2020). Analysis of cognitive skills in History textbook (Spain-England-Portugal). Frontiers in Psychology. https://doi.org/10.3389/fpsyg.2020.521115

Lage, M. J., Platt, G. J., \& Treglia, M. (2000). Inverting the classroom: A gateway to creating an inclusive learning environment. Journal of Economic Education, 31, 30-43. https://doi.org/10.1080/00220480009596759

Lee, P. (2005). Putting principles into practice: Understanding History. In M. Donovan \& J. Bransford (Eds.), How students learn: History in the classroom (pp. 31-77). National Academies Press.

Lee, P. (2011). History education and historical literacy. In I. Davies (Ed.), Debates in History teaching (pp. 63-72). Routledge.

Lévesque, S. (2008). Thinking historically: Educating students for the 21st century. University of Toronto Press.

Molina, J., Trigueros, F. J., \& Miralles, P. (2017). Las competencias en las clases de historia: Percepciones del alumnado sobre el proceso evaluador [Competences in history lessons: Student perceptions of the assessment process] (pp. 167-187). GRAÓ.

Nokes, J. D. (2010). Observing literacy practices in History classrooms. Theory \& Research in Social Education, 38(4), 515-544. https://doi.org/10.1080/00933104.2010.10473438 
OECD. (2020) OECD skills strategy 2019: Skills for a better future. OECD Publishing and Fundación Santillana. https://dx.doi.org/10.1787/e3527cfb-es

Pagès, J. (2009). El desarrollo del pensamiento histórico como requisito para la formación democrática de la ciudadanía [The development of historical thought as a requirement for the democratic formation of citizenship]. Reseñas de Enseñanza de la Historia [History Teaching Reviews], 7, 69-91. https://pagines.uab.cat/joan_pages/sites/pagines.uab.cat.joan_pages/files/20 09_Pages_Rese\%c3\%b1as_7.pdf

Prats, J., \& Santacana, J. (2011). ¿Por qué y para qué enseñar Historia? [Why and why teach History?]. In L. F. Rodríguez \& N. García (Eds.), Enseñanza, aprendizaje de la historia en la educación básica [Teaching, learning History in basic education] (pp. 18-68). Universidad Pedagógica Nacional [National Pedagogical University].

Real Decreto [Royal Decree] 1105 (2014, December 26). Por el que se establece el currículo básico de la educación secundaria obligatoria y del bachillerato. BOE n. 3 de 2015 (3 de Enero) [Establishing the basic curriculum for compulsory secondary education and the baccalaureate. BOE no. 3 of 2015 (3 January)].

Sáiz, J. (2014). Fuentes históricas y libros de texto en secundaria: Una oportunidad perdida para enseñar competencias de pensamiento histórico [High school History resources and textbooks: A missed opportunity to teach historical thinking competencies]. Ensayos: Revista de la Facultad de Educación de Albacete [Essays: Magazine of the Faculty of Education of Albacete], 29(1), 83-99. https://doi.org/10.18239/ensayos.v29i1.503

Sáiz, J. (2015). Educación histórica y narrativa nacional [National historical and narrative education] (Doctoral thesis). Universitat de València, Valencia, Spain.

Seixas, P., \& Peck, C. (2004). Teaching historical thinking. In A. Sears \& I. Wright, Challenges and prospects for Canadian social studies (pp. 109-117). Pacific Educational Press.

Schwerdt, G., \& Wuppermann, A. C. (2011). Is traditional teaching really all that bad? A within-student between-subject approach. Economics of Education Review, 30(2), 365-379. https://doi.org/10.1016/j.econedurev.2010.11.005

Trigueros, F. J., Molina, J., Álvarez, J. M. (2017). La enseñanza de la historia y el desarrollo de competencias sociales y cívicas [History teaching and the development of social and civic skills]. Clío: History and History Teaching, 43, 1-10.

Valls, R., \& Parra, D. (2016). Libros de texto: Una visión simplificada [Textbooks: A simplified view]. Iber: Didáctica de las Ciencias Sociales, Geografía e Historia [Iber: Didactics of Social Sciences, Geography and History], 85, 15-19. https://dialnet.unirioja.es/ejemplar/441033

Van Nieuwenhuyse, K. (2016). Reasoning with and/or about sources on the Cold War? The use of primary sources in English and French History education. International Journal for History and Social Sciences Education, 1, 19-51. https://www.pacinieditore.it/wp-content/uploads/2017/11/karel-vannieuwenhuyse-reasoning-with-andor-about-sources-on-the-cold-war.pdf

VanSledright, B. A. (2014). Assessing historical thinking and understanding: Innovation design for new standards. Routledge.

Wineburg, S. (2001). Historical thinking and other unnatural acts: Charting the future of teaching the past. Temple University Press. 


\section{Appendix}

Álvarez, L., Garcia, M., Gatell, C., \& Gibaja, J. C., Palafox., J., \& Risques, M. (2016). HMC. Historia del mundo contemporáneo [History of the contemporary world]. Vicens Vives.

Anderson, L. W., Cepeda, J., Cepeda, P., Gómez, F., Calvo, A., Herrero, M., \& Martín, M. (2015). Historia del mundo contemporáneo [History of the contemporary world]. Oxford University Press.

Fernández, J. M., Gonzalez, J., \& Ramirez, A. (2015). Historia del mundo contemporáneo [History of the contemporary world]. Santillana.

Fossati, M., Luppi, G., \& Zanette, E. (2016). Senso Storico: Il Novecento e il mondo contemporáneo 3 [Historical sense. The twentieth century and the contemporary world] (Edizioni Scolastiche Bruno Mondadori). Pearson Italia.

Gentile, G., Ronga, L., \& Rossi, A. (2016). Il nuovo Millennium 3 [The new Millennium 3]. Editrice La Scuola.

Otero, L. E. (2015). Historia del mundo contemporáneo [History of the contemporary world]. Ed. SM.

Paolucci, S., Signorini, G., \& Marisaldi, L. (2017). Di tempo in tempo 3. L’Età contemporánea [From time to time 3: The contemporary age]. Zanichelli.

Prats, J., Moradiellos, E., Gil, C., Rivero, M. P., \& Sobrino, D. (2015). Historia del mundo contemporáneo [History of the contemporary world]. Anaya. 